\title{
A Decade of Cerebrospinal Fluid Biomarkers for Alzheimer's Disease in Belgium
}

Charisse Somers $^{\mathrm{a}}$, Hanne Struyfs ${ }^{\mathrm{a}}$, Joery Goossens ${ }^{\mathrm{a}}$, Ellis Niemantsverdriet ${ }^{\mathrm{a}}$, Jill Luyckx ${ }^{\mathrm{a}}$, Naomi De Roeck ${ }^{\mathrm{a}}$, Ellen De Roeck ${ }^{\mathrm{a}}$, Bart De Vil ${ }^{\mathrm{d}}$, Patrick Cras ${ }^{\mathrm{d}, \mathrm{e}}$, Jean-Jacques Martin ${ }^{\mathrm{c}}$, Peter-Paul De Deyn ${ }^{\mathrm{a}, \mathrm{b}, \mathrm{c}}$, Maria Bjerke ${ }^{\mathrm{a}}$ and Sebastiaan Engelborghs ${ }^{\mathrm{a}, \mathrm{b}, *}$

${ }^{a}$ Reference Center for Biological Markers of Dementia (BIODEM), Laboratory of Neurochemistry and Behavior, Institute Born-Bunge, University of Antwerp, Antwerp, Belgium

${ }^{\mathrm{b}}$ Department of Neurology and Memory Clinic, Hospital Network Antwerp (ZNA) Middelheim and Hoge Beuken, Antwerp, Belgium

${ }^{\mathrm{c}}$ Biobank, Institute Born-Bunge, University of Antwerp, Antwerp, Belgium

${ }^{\mathrm{d}}$ Laboratory of Neurobiology, Institute Born-Bunge, University of Antwerp, Antwerp, Belgium

${ }^{\mathrm{e}}$ Department of Neurology, Antwerp University Hospital, Antwerp, Belgium

Handling Associate Editor: Daniela Galimberti

Accepted 7 June 2016

\begin{abstract}
During the past ten years, over 5,000 cerebrospinal fluid (CSF) samples were analyzed at the Reference Center for Biological Markers of Dementia (BIODEM), UAntwerp, for core Alzheimer's disease (AD) CSF biomarkers: amyloid$\beta$ peptide of 42 amino acids $\left(A \beta_{1-42}\right)$, total tau protein (T-tau), and tau phosphorylated at threonine $181\left(\mathrm{P}-\operatorname{tau}_{181 \mathrm{P}}\right)$. CSF biomarker analyses were performed using single-analyte ELISA kits. In-house validated cutoff values were applied: $\mathrm{A} \beta_{1-42}$ $<638.5 \mathrm{pg} / \mathrm{mL}, \mathrm{T}$-tau $>296.5 \mathrm{pg} / \mathrm{mL}$, P-tau $181 \mathrm{P}>56.5 \mathrm{pg} / \mathrm{mL}$. A CSF biomarker profile was considered to be suggestive for $\mathrm{AD}$ if the CSF $\mathrm{A} \beta_{1-42}$ concentration was below the cutoff, in combination with T-tau and/or P-tau $181 \mathrm{P}$ values above the cutoff (IWG2 criteria for $\mathrm{AD}$ ). Biomarker analyses were requested for following clinical indications: 1) neurochemical confirmation of $\mathrm{AD}$ in case of clinical $\mathrm{AD}, 2)$ neurochemical confirmation of $\mathrm{AD}$ in case of doubt between $\mathrm{AD}$ and a non- $\mathrm{AD}$ dementia, 3) neurochemical diagnosis of prodromal $\mathrm{AD}$ in case of mild cognitive impairment, 4) neurochemical confirmation of $\mathrm{AD}$ in case of psychiatric symptoms (like depression, psychosis), or 5) other clinical indications. During these ten years, the number of yearly referred samples increased by $238 \%$ and clinical indications for referral showed a shift from neurochemical confirmation of $\mathrm{AD}$ in case of clinical $\mathrm{AD}$ to differential dementia diagnosis in case of doubt between $\mathrm{AD}$ and a non-AD dementia. Four percent of the patients also had a postmortem neuropathological examination. Together, these biomarker data were the basis for several research papers, and significantly contributed to the validation of these biomarkers in autopsy-confirmed subjects.
\end{abstract}

Keywords: Alzheimer's disease, amyloid, biomarkers, cerebrospinal fluid, dementia, diagnosis, mild cognitive impairment, neuropathology, tau

\footnotetext{
${ }^{*}$ Correspondence to: Prof. Dr. Sebastiaan Engelborghs, Reference Center for Biological Markers of Dementia (BIODEM), University of Antwerp, Universiteitsplein 1, BE2610 Antwerp, Belgium. Tel.: +323 26523 94; E-mail: sebastiaan.engelborghs@uantwerpen.be.
}

\section{INTRODUCTION}

The past two decades, much effort has been put in developing biomarkers for Alzheimer's disease (AD) [1-6]. This resulted in three core cerebrospinal fluid (CSF) biomarkers for $\mathrm{AD}$ diagnostics, namely the 
42 amino acid long amyloid-beta peptide $\left(\mathrm{A} \beta_{1-42}\right)$, total tau protein (T-tau), and tau phosphorylated at threonine 181 (P-tau $181 \mathrm{P})$ [7]. A $\beta$ and both tau proteins can reliably be measured in CSF by the use of several analytical techniques including single-analyte enzyme-linked immunosorbent assays (ELISA) [8].

Biomarkers have been incorporated into research diagnostic criteria for AD [9-11] and, although the clinical examination (including full neuropsychological evaluation) is still the basis for AD diagnosis [12], these biomarkers are being introduced in daily clinical dementia practice as in vivo surrogate markers for the confirmation of AD neuropathology. The core CSF AD biomarkers increase the diagnostic accuracy for diagnosing $\mathrm{AD}$ (including cases with atypical presentations), also in its prodromal phase (mild cognitive impairment (MCI) due to AD) $[1,4]$, and are able to differentiate between $\mathrm{AD}$ and psychiatric disorders. The CSF biomarkers are useful to diagnose $\mathrm{AD}$ in patients with ambiguous clinical dementia diagnoses $[13,14]$ and in cases with mixed brain pathology like AD with cerebrovascular disease [15-17].

At the Reference Center for Biological Markers of Dementia (BIODEM), UAntwerp, CSF samples from referring clinical centers have been analyzed for the core AD CSF biomarkers since 2004. In what follows, an overview of a decade of CSF biomarker analyses at BIODEM will be given. This overview includes over 5,000 neurochemical analyses. Four percent of the patients also had a postmortem neuropathological examination. Together, these biomarker data were the basis for several research papers. This overview forms a basis for revealing limitations and providing new insights to improve the neurochemical diagnosis of AD.

\section{METHODOLOGY}

\section{CSF samples from referring clinical centers}

CSF samples from patients with presumed cognitive deterioration were referred to the BIODEM lab. Since 2004, clinical centers from all over Belgium as well as some international centers have been referring samples (Fig. 1). CSF biomarker analyses were requested by the physicians in the context of a diagnostic workup. The physicians were asked to fill out a request form consisting of the patient's age, gender, Mini-Mental State Examination (MMSE) score [18], sampling date, and the clinical indication for referral, that consisted of one of the following options (tick boxes):

1) Neurochemical confirmation of $\mathrm{AD}$ in case of clinical AD. CSF biomarkers were used to increase the diagnostic accuracy.

2) Neurochemical confirmation of $A D$ in case of doubt between $\mathrm{AD}$ dementia and a non-AD dementia, including atypical clinical presentations of $\mathrm{AD}$, possible dementia with Lewy bodies (DLB), possible frontotemporal lobar degeneration (FTLD), possible vascular dementia (VaD), Creutzfeldt-Jakob's disease (CJD), etc.

3) Neurochemical confirmation of prodromal AD in case of MCI.

4) Neurochemical confirmation of $\mathrm{AD}$ in case of psychiatric symptoms (like depression, psychosis).

5) Other clinical indication: the referring clinician was asked to provide additional clinical information.

In case of CJD confirmation or $\mathrm{AD}$ versus $\mathrm{CJD}$ differential diagnosis, additional analysis of 14-3-3 protein could be requested [19-21].

\section{CSF sampling and handling}

All CSF sampling and handling steps are represented in Fig. 2. In short, CSF was obtained by lumbar puncture (LP) at the L3/L4 or L4/L5 interspace (Engelborghs et al., unpublished). Referring centers were asked to perform CSF sample handling and processing according to the standard procedure as described in the BIODEM lab guidelines (http://www.bornbunge.be). This includes collection of minimal $2 \mathrm{ml} \mathrm{CSF}$ in a labeled polypropylene tube to avoid adsorption of $A \beta$ to the wall of the vial. In case of a hemorrhagic LP detected by macroscopic inspection, CSF should be centrifuged for $10 \mathrm{~min}$ at $3000 \mathrm{rpm}$ within $4 \mathrm{~h}$ after LP. The supernatant should thereafter be transferred to an unused polypropylene vial. CSF samples should be shipped to the BIODEM lab, unfrozen if sent within $24 \mathrm{~h}$ after LP (shipment at room temperature) or frozen if sent later (shipment on dry ice). Samples were stored at $-80^{\circ} \mathrm{C}$ until analysis.

\section{CSF analysis}

CSF concentrations of $A \beta_{1-42}$, T-tau, and P-tau $181 \mathrm{P}$ were determined with commercially available singleanalyte ELISA kits (INNOTEST® $\beta$-Amyloid(1-42), INNOTEST ${ }^{\circledR}$ hTau-Ag, and INNOTEST ${ }^{\circledR}$ Phospho- 

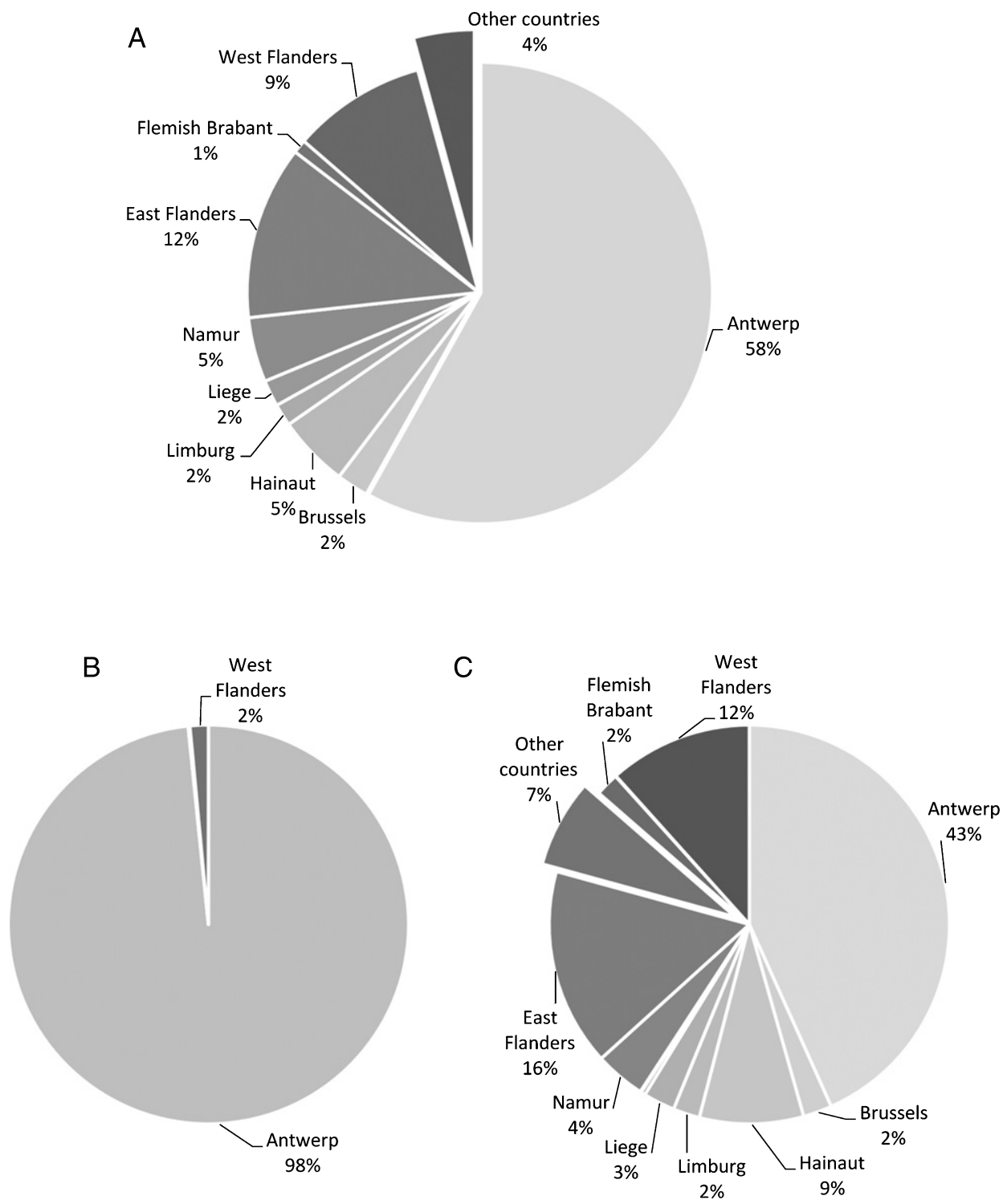

Fig. 1. National and international locations of the centers referring samples between 2004 and 2014 (A). Locations of the referring centers subdivided in a time range of 2004-2006 (B) and 2012-2014 (C).

Tau(181P), respectively; Fujirebio Europe, Ghent, Belgium). With each assay the clinical samples, together with a blank (sample diluent), calibrator solutions, and appropriate quality controls, were analyzed according to the manufacturer's instructions as described previously [2]. The 14-3-3 protein analyses were performed using western blot [22].

As described in the IWG 2 criteria for $\mathrm{AD}$, a CSF biomarker profile was considered pathological and suggestive for $\mathrm{AD}$ if the analysis resulted in a low CSF $A \beta_{1-42}$ value in combination with increased levels of T-tau and/or P-tau $181 \mathrm{P}$ [10]. Cutoffs used for the determination of normal values are $A \beta_{1-42}>638.5$ $\mathrm{pg} / \mathrm{ml}$, T-tau $<296.5 \mathrm{pg} / \mathrm{ml}$, and P-tau $181 \mathrm{P}<56.5 \mathrm{pg} / \mathrm{ml}$ as determined in a cohort of autopsy-confirmed AD patients and cognitively healthy elderly [23].

As a part of the Alzheimer's Association Quality Control (QC) Program for CSF biomarkers, the performance of the assays was monitored with CSF QC samples provided by the program. Two different longitudinal samples were included in the routine ELISA analyses since 2010. Sample characteristics and procedures have been described previously by Mattsson et al. [24]. 


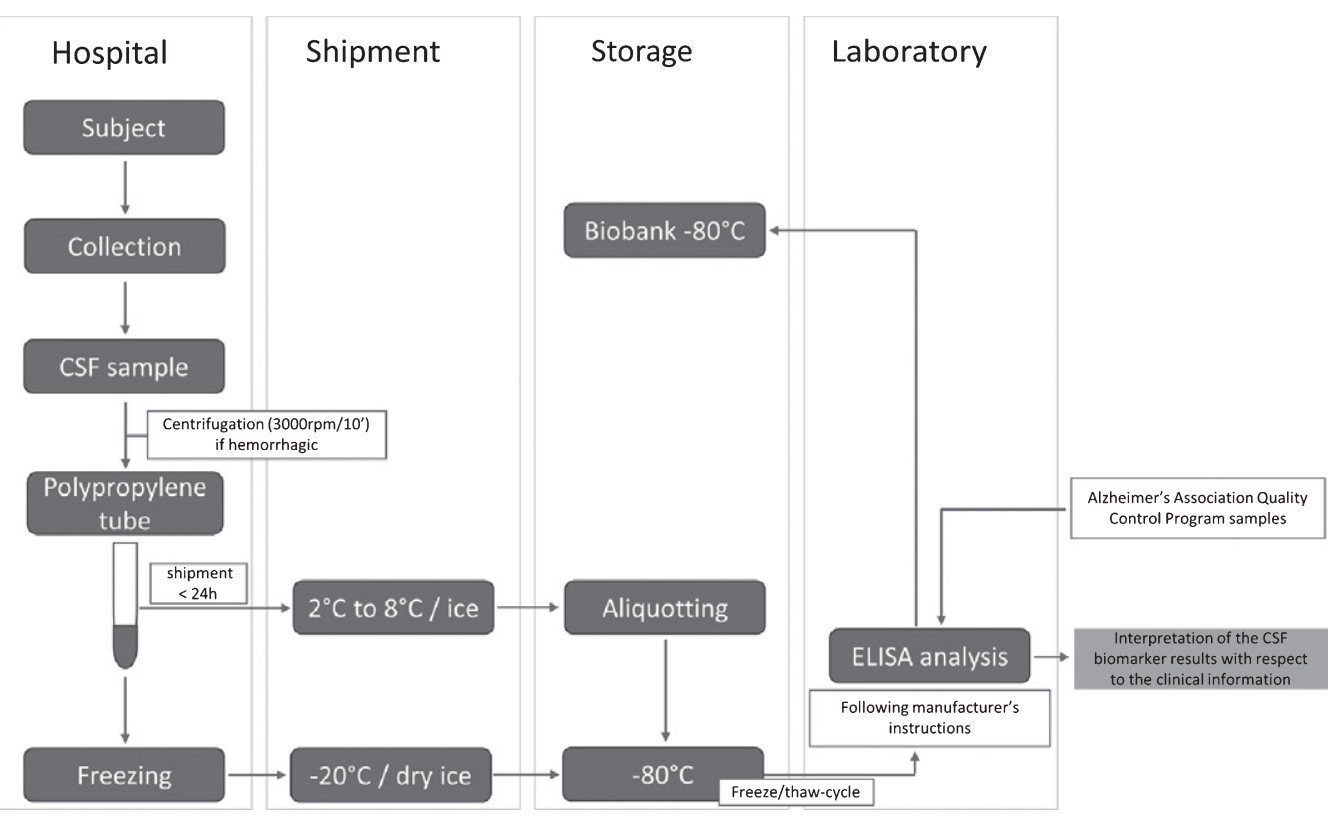

Fig. 2. Workflow of the pre-analytical, analytical and post-analytical steps of the BIODEM lab for CSF biomarker analyses at the BIODEM lab.

\section{Informed consent for research purposes}

Whenever possible, patients were asked to give written informed consent to use CSF leftovers for scientific research as well as to undergo brain autopsy after death $[2,13]$. In case consented patients died, a brain autopsy was performed according to a standard protocol $[2,13]$. Neuropathological examination was performed on the right hemisphere of the brain at the Biobank of the Institute Born-Bunge (Antwerp, Belgium). Patients were neuropathologically diagnosed as definite $\mathrm{AD}$, DLB and $\mathrm{VaD}$ using the criteria of Montine [25]. Definite FTLD was diagnosed through the criteria of Cairns [26] and Mackenzie [27, 28], while definite CJD was diagnosed in agreement with the criteria of Markesbery [29].

\section{Statistical analyses}

The variables were assessed for normal distribution using the Kolmogorov-Smirnov test. Since variables were not normally distributed, nonparametric tests were performed. For comparisons across groups, Kruskal-Wallis and Mann-Whitney tests were applied. Chi-Square tests were performed to explore gender distributions. Spearman's $\rho$ was calculated to determine correlations. Confidence intervals (CI) were established at 95\%. The level of significance was set at $p<0.05$. The diagnostic accuracies of the autopsy-confirmed patients was obtained by receiver operating characteristics (ROC) curve analysis for the determination of the area under the curve (AUC), sensitivities, specificities and the optimal cutoff for the differentiation of $\mathrm{AD}$ and non-AD dementia diagnosis. The optimal cutoff values were determined by calculation of the maximal sum of the sensitivity and the specificity. All statistical analyses were done using SPSS statistical package of IBM Statistics, version 22.

\section{RESULTS}

\section{Description of the population}

Table 1 shows the demographic and clinical characteristics of the patients. The database contains samples of a total of 5,022 patients with an equal distribution of males and females. The mean age at time of CSF sampling was 71 years. A proportion of the population (4\%) received an autopsy-confirmed diagnosis. For a subgroup of 1,710 patients, the MMSE scores at time of CSF biomarker analysis request were available. Patients who were referred for neurochemical confirmation of $\mathrm{AD}$ or for differential $\mathrm{AD}$ versus non-AD dementia diagnosis showed significantly lower MMSE scores as compared to the prodromal $\mathrm{AD}$ group, and the patients who were referred for a neurochemical diagnosis of $\mathrm{AD}$ in case of psychiatric 
symptoms and other indications $(p<0.001)$. During the past ten years, the mean MMSE scores remained unchanged (results not shown). Indeed, the relative number of samples from patients referred for neurochemical confirmation of prodromal AD did not increase significantly.

\section{Referral of CSF samples from 2004-2014}

Between 2004 and 2014, the analyses of unique samples per year have increased from 238 in 2004 to 804 in 2014 (Fig. 3A). Where initially only Antwerp centers referred samples in 2004, increasing to 381 in 2014, more and more centers from other regions in Belgium started referring samples throughout the years, leading to a total of 423 in 2014 (Fig. 3B). The relative amount of patients per indication (Fig. 3C) demonstrates a switch at the timepoint of the second quarter of 2011 from the majority of requests concerning neurochemical confirmation of $\mathrm{AD}$, to most referrals being for differential dementia diagnosis. Samples referred for neurochemical diagnosis of AD in case of psychiatric symptoms also become slightly more frequent over time. The number of samples referred for other indications, such as CJD, shows a decrease over time. Over the time course of ten years, the number of samples referred for diagnosis of prodromal $\mathrm{AD}$ in case of MCI was stable.

\section{Results of CSF biomarker analyses}

The mean biomarker concentrations are described in Table 1. All three CSF biomarkers were analyzed in 4983 of the 5025 samples, while the remaining samples were tested only for T-tau $(n=16)$, $\mathrm{A} \beta_{1-42}(n=4)$, or P-tau $181 \mathrm{P}(n=2)$ or two of the three biomarkers $(n=20)$. All samples were analyzed in duplicates. These missing data are due to insufficient sample volume to analyze all three biomarkers and/or reanalyze biomarkers in case the coefficient of variation (100*standard deviation/mean) exceeded $20 \%$. Of the entire study population, $39 \%(n=1,956)$ had a neurochemical profile indicative for AD pathology, based on the IWG2 criteria [10]. Samples with a normal CSF biomarker profile accounted for $22 \%$ $(n=1,123)$. This leaves another $39 \%(n=1,943)$ of the samples unclassifiable by the IWG2 criteria, including samples presenting with normal $A \beta_{1-42}$ but increased T-tau and/or P-tau $181 \mathrm{P}$ concentrations $(n=724)$ and samples presenting with low $\mathrm{A} \beta_{1-42}$ $(<638.5 \mathrm{pg} / \mathrm{ml})$ but normal T-tau and P-tau $181 \mathrm{P}$ concentrations $(n=1,181)$. Thirty-eight samples could not be categorized due to missing analyses of one or two of the CSF biomarkers. Of the 261 samples with very high T-tau values $(>1,200 \mathrm{pg} / \mathrm{ml}$; value higher than the upper limit of quantification of the test kits used for analysis, as described in the package inserts), 95 samples were analyzed for 14-3-3 protein of which 69 samples were positive.

In total, 170 patients had autopsy-confirmed diagnoses of which 108 with AD pathology and 62 with non-AD pathology (Table 2). Six out of 108 subjects (6\%) were autopsy-confirmed AD patients who presented with normal CSF biomarker levels of $A \beta_{1-42}$, T-tau, and P-tau $181 \mathrm{P}$, three subjects (3\%) with normal $\mathrm{A} \beta_{1-42}$ but increased T-tau and/or P-tau $181 \mathrm{P}$, and 15 subjects $(14 \%)$ with low $\mathrm{A} \beta_{1-42}(<638.5 \mathrm{pg} / \mathrm{ml})$ but normal T-tau and P-tau $181 \mathrm{P}$ levels. The biomarker profiles of these neuropathologically confirmed AD patients therefore do not comply with the IWG2 criteria for AD biomarker diagnosis. Of the autopsyconfirmed non-AD patients, 27 subjects $(44 \%)$ had a CSF neurochemical profile that was in compliance with the IWG2 criteria for AD biomarker diagnosis. In 16 subjects (9\% of the total number of autopsyconfirmed patients) a neurochemical diagnosis could not be established due to analysis of only $A \beta_{1-42}$ or T-tau levels. Thirteen patients with very high T-tau levels $(>1,200 \mathrm{pg} / \mathrm{ml})$ were autopsy-confirmed CJD. Four of these patients scored negative for 14-3-3 protein. Of the 70 samples with positive 14-3-3 protein analysis, one sample showed to be autopsy-confirmed hippocampal sclerosis. Inter-biomarker correlations and correlations of the biomarkers with age at LP and MMSE score are presented in Table 3. The diagnostic accuracies and optimal cutoff values determined for the individual markers as well as the $\mathrm{A} \beta_{1-42} / \mathrm{T}$-tau and $\mathrm{A} \beta_{1-42} / \mathrm{P}-\operatorname{tau}_{181 \mathrm{P}}$ ratios are shown in Table 4.

\section{Alzheimer's Association QC program for CSF biomarkers}

The results of the Alzheimer's Association QC Program first and second longitudinal QC (QC-L) samples are shown in Fig. 4. A second longitudinal QC sample was used in succession of the first due to a supply shortage. All BIODEM results were within the 2SD range calculated from the mean value of all participating laboratories. The inter-run $\mathrm{CV}$ was $14 \%, 16 \%$ and $8 \%$ for $A \beta_{1-42}$, T-tau and P-tau $181 \mathrm{P}$, respectively, for the first QC-L and 12\%, 16\%, and 6\% for the second QC-L. No shift occurred for the three biomarkers (i.e., a systematic error, where results of six consecutive measurements lie on the same side of 
Table 1

Demographic and clinical data. Biomarker concentrations that were found to be abnormal can be indicative for AD pathology, following the AD profile cutoff points: $A \beta_{1-42}<638,5 \mathrm{pg} / \mathrm{ml}$, T-tau $>296,5 \mathrm{pg} / \mathrm{ml}$ and P-tau $181 \mathrm{P}>56,5 \mathrm{pg} / \mathrm{ml}$. Other autopsy-confirmed diagnosis involves hippocampal sclerosis, progressive supranuclear palsy and anoxic necrosis

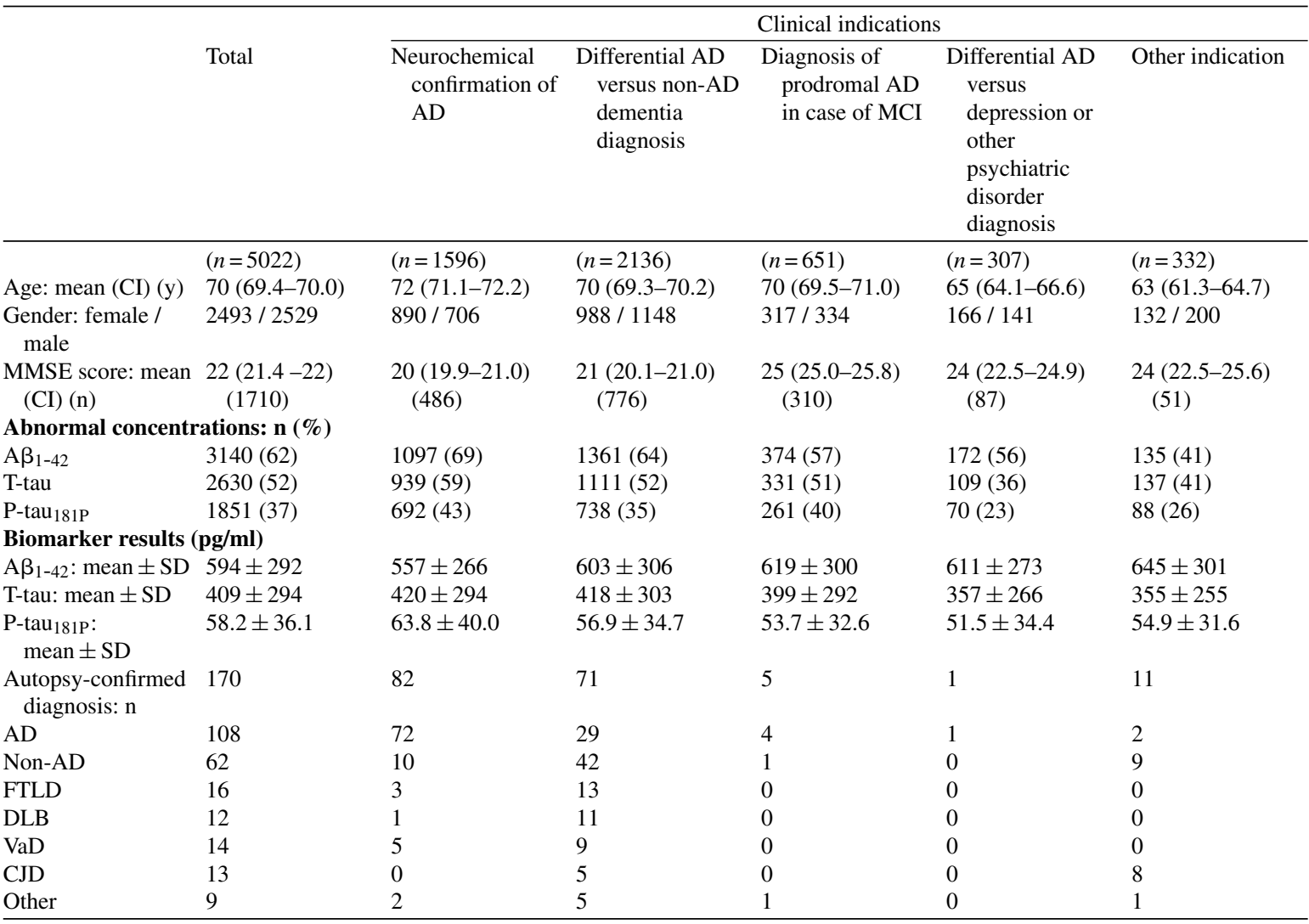

the mean) nor was there a visible trend for all three biomarkers (i.e., a systematic error, were the measurements move in one direction, heading towards an 'out-of-control' value).

\section{DISCUSSION}

During ten years of AD CSF biomarker analyses, the amount of samples referred to the BIODEM lab at UAntwerp from clinical centers has increased with $238 \%$. Due to the revisions of diagnostic criteria for $\mathrm{AD}$ diagnosis and the herein described use of CSF biomarkers [9-11], confidence in the importance of biomarkers has grown. Not only are they used more often by clinicians, they are also useful in clinical trials as enrichment strategy or outcome measures due to their in vivo pathophysiological characteristics [30]. The observed increase of referrals could also have been influenced by different milestones, e.g. the publications of biomarker-based diagnostic criteria for $\mathrm{AD}$. These specific milestones did not show clear associations with the time course of the number of samples referred. However, there is a general shift from samples referred for neurochemical confirmation of $\mathrm{AD}$ diagnosis to referrals for differential AD versus non-AD dementia diagnosis. This may be due to the growing scientific support for biomarker-based differential diagnosis between $\mathrm{AD}$ and non-AD dementias [13, 14, 31-33].

Several research papers found their origin in the BIODEM database of AD CSF biomarker analyses and an important contribution is ascribed to the subjects that gave informed consent for brain autopsy. Our lab was the first to demonstrate the diagnostic value of the CSF biomarkers $A \beta_{1-42}$, T-tau, and P-tau $181 \mathrm{P}$ in clinical AD, using the neuropathological diagnosis as a reference $[2,34]$. The data demonstrated that all three biomarkers provide useful information, showing promising sensitivity and specificity values that systematically exceed the $80 \%$ threshold. The use of a biomarker-based model 
Table 2

AD CSF biomarker profile and biomarker levels of autopsy-confirmed $\mathrm{AD}$ and non-AD dementia patients. n.s., no significant differences

\begin{tabular}{|c|c|c|c|}
\hline & $\begin{array}{c}\mathrm{AD} \\
(n=108)\end{array}$ & $\begin{array}{c}\text { Non-AD } \\
(n=62)\end{array}$ & Significance \\
\hline \multicolumn{4}{|l|}{ Normal } \\
\hline $\mathrm{n}$ & 6 & 7 & \\
\hline T-tau mean $\pm \mathrm{SD}(\mathrm{pg} / \mathrm{ml})$ & $212 \pm 49$ & $244 \pm 33$ & n.s. \\
\hline $\mathrm{A} \beta_{1-42}$ mean $\pm \mathrm{SD}(\mathrm{pg} / \mathrm{ml})$ & $914 \pm 209$ & $962 \pm 188$ & n.s. \\
\hline P-tau $181 \mathrm{P}$ mean $\pm \mathrm{SD}(\mathrm{pg} / \mathrm{ml})$ & $41.4 \pm 9.3$ & $40.0 \pm 5.2$ & n.s. \\
\hline $\mathrm{A} \beta_{1-42} / \mathrm{T}$-tau mean $\pm \mathrm{SD}$ & $4.38 \pm 0.64$ & $3.99 \pm 0.84$ & n.s. \\
\hline $\mathrm{A} \beta_{1-42} / \mathrm{P}-\operatorname{tau}_{181 \mathrm{P}}$ mean $\pm \mathrm{SD}$ & $22.62 \pm 5.59$ & $24.16 \pm 4.30$ & n.s. \\
\hline Age at LP & $78 \pm 6$ & $71 \pm 6$ & n.s. \\
\hline MMSE score & $24 \pm 2$ & $17 \pm 15$ & n.s. \\
\hline \multicolumn{4}{|l|}{ Suggestive for AD } \\
\hline $\mathrm{n}$ & 72 & 27 & \\
\hline T-tau mean $\pm \mathrm{SD}(\mathrm{pg} / \mathrm{ml})$ & $585 \pm 216$ & $446 \pm 155$ & n.s. \\
\hline $\mathrm{A} \beta_{1-42}$ mean $\pm \mathrm{SD}(\mathrm{pg} / \mathrm{ml})$ & $402 \pm 131$ & $435 \pm 134$ & n.s. \\
\hline P-tau $181 \mathrm{P}$ mean $\pm S D(\mathrm{pg} / \mathrm{ml})$ & $84.0 \pm 42.9$ & $61.6 \pm 34.8$ & $p=0.001$ \\
\hline $\mathrm{A} \beta_{1-42} / \mathrm{T}$-tau mean $\pm \mathrm{SD}$ & $0.72 \pm 0.42$ & $0.88 \pm 0.58$ & n.s. \\
\hline $\mathrm{A} \beta_{1-42} / \mathrm{P}-\operatorname{tau}_{181 \mathrm{P}}$ mean $\pm \mathrm{SD}$ & $5.61 \pm 2.91$ & $8.62 \pm 4.08$ & $p<0.001$ \\
\hline Age at LP & $76 \pm 13$ & $74 \pm 10$ & n.s. \\
\hline MMSE score & $15 \pm 7$ & $19 \pm 7$ & n.s. $(p=0.58)$ \\
\hline \multicolumn{4}{|c|}{ Normal $A \beta_{1-42}$ but increased T-tau and/or P-tau $181 P$} \\
\hline $\mathrm{n}$ & 3 & 13 & \\
\hline T-tau mean $\pm \mathrm{SD}(\mathrm{pg} / \mathrm{ml})$ & $552 \pm 134$ & $481 \pm 204$ & n.s. \\
\hline $\mathrm{A} \beta_{1-42}$ mean $\pm \mathrm{SD}(\mathrm{pg} / \mathrm{ml})$ & $702 \pm 57$ & $832 \pm 116$ & n.s. $(p=0.057)$ \\
\hline $\mathrm{P}-\mathrm{tau}_{181 \mathrm{P}}$ mean $\pm \mathrm{SD}(\mathrm{pg} / \mathrm{ml})$ & $78.9 \pm 24.9$ & $59.9 \pm 23.3$ & n.s. \\
\hline $\mathrm{A} \beta_{1-42} / \mathrm{T}$-tau mean $\pm \mathrm{SD}$ & $1.17 \pm 0.67$ & $1.56 \pm 0.77$ & n.s. \\
\hline $\mathrm{A} \beta_{1-42} / \mathrm{P}-\operatorname{tau}_{181 \mathrm{P}}$ mean $\pm \mathrm{SD}$ & $20.53 \pm 6.38$ & $15.83 \pm 6.01$ & n.s. \\
\hline Age at LP & $81 \pm 5$ & $67 \pm 9$ & $p=0.014$ \\
\hline MMSE score & $18 \pm 6$ & $19 \pm 7$ & n.s. \\
\hline \multicolumn{4}{|c|}{ Low $A \beta_{1-42}$ but normal T-tau and P-tau $181 P$} \\
\hline $\mathrm{n}$ & 15 & 11 & \\
\hline T-tau mean $\pm \mathrm{SD}(\mathrm{pg} / \mathrm{ml})$ & $117 \pm 54$ & $166 \pm 65$ & $p=0.033$ \\
\hline $\mathrm{A} \beta_{1-42}$ mean $\pm \mathrm{SD}(\mathrm{pg} / \mathrm{ml})$ & $324 \pm 117$ & $408 \pm 154$ & n.s. \\
\hline $\mathrm{P}-\mathrm{tau}_{181 \mathrm{P}}$ mean $\pm \mathrm{SD}(\mathrm{pg} / \mathrm{ml})$ & $30.9 \pm 7.6$ & $25.7 \pm 8.9$ & n.s. $(p=0.066)$ \\
\hline $\mathrm{A} \beta_{1-42} / \mathrm{T}$-tau mean $\pm \mathrm{SD}$ & $1.95 \pm 0.90$ & $3.00 \pm 2.07$ & n.s. \\
\hline $\mathrm{A} \beta_{1-42} / \mathrm{P}-\operatorname{tau}_{181 \mathrm{P}}$ mean $\pm \mathrm{SD}$ & $11.84 \pm 6.10$ & $14.44 \pm 9.04$ & n.s. \\
\hline Age at LP & $72 \pm 14$ & $69 \pm 10$ & n.s. \\
\hline MMSE score & $16 \pm 7$ & $19 \pm 3$ & n.s. \\
\hline
\end{tabular}

Table 3

Correlations between the three biomarkers and correlations between the biomarkers and the clinical data of the autopsy-confirmed AD and non-AD dementia patients. Correlations are shown by 'Spearman's $\rho$ ( $p$-value)'; n.s., not significant

\begin{tabular}{|c|c|c|c|c|c|}
\hline & & T-tau (pg/ml) & $\mathrm{A} \beta_{1-42}(\mathrm{pg} / \mathrm{ml})$ & Age at LP & MMSE score \\
\hline \multirow[t]{3}{*}{$\overline{A D}$} & T-tau (pg/ml) & - & - & n.s. & $-0.320(p=0.004)$ \\
\hline & $\mathrm{A} \beta_{1-42}(\mathrm{pg} / \mathrm{ml})$ & n.s. & - & n.s. & n.s. \\
\hline & P-tau $181 \mathrm{P}(\mathrm{pg} / \mathrm{ml})$ & $0.726(p<0.001)$ & n.s. & n.s. & n.s. \\
\hline \multirow[t]{3}{*}{ non-AD } & T-tau (pg/ml) & - & - & n.s. & n.s. \\
\hline & $\mathrm{A} \beta_{1-42}(\mathrm{pg} / \mathrm{ml})$ & n.s. & - & n.s. & n.s. \\
\hline & P-tau $181 \mathrm{P}(\mathrm{pg} / \mathrm{ml})$ & $0.618(p<0.001)$ & $0.307(p=0.016)$ & $0.257(p=0.045)$ & n.s. \\
\hline
\end{tabular}

in patients with a clinically ambiguous diagnosis, resulted in a correct diagnosis in the majority of autopsy-confirmed $\mathrm{AD}$ and non-AD cases, indicating that biomarkers have an added diagnostic value in these cases [12]. Moreover, the diagnostic value of the AD biomarkers $A \beta_{1-42}$, T-tau, and P-tau $181 \mathrm{P}$ is independent of the platform (single-analyte ELISA or multiplex) on which they are tested, despite the differences in absolute values, provided that appropriate cutoff points are being used [8].

Investigating autopsy-confirmed $\mathrm{AD}$ and non-AD dementia patients has also improved our knowledge and insights with regard to the differential diagnostic value of the existing AD CSF biomarkers. The ratio of $A \beta_{1-42} / \mathrm{P}-\operatorname{tau}_{181} \mathrm{P}$ was shown to have a higher diagnostic accuracy (sensitivity of $73.5 \%$ 

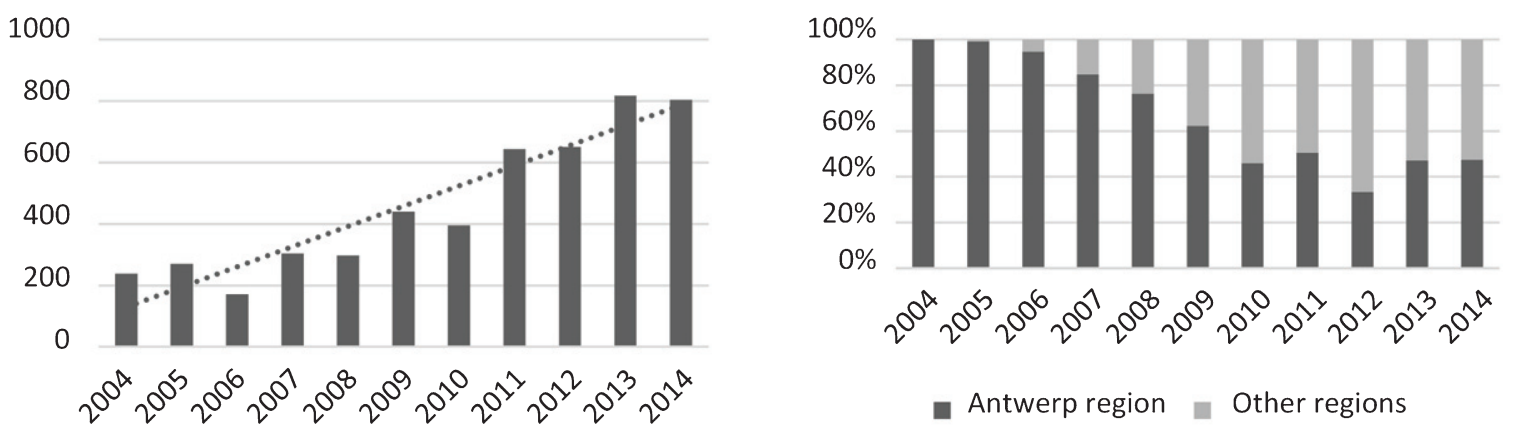

A

B

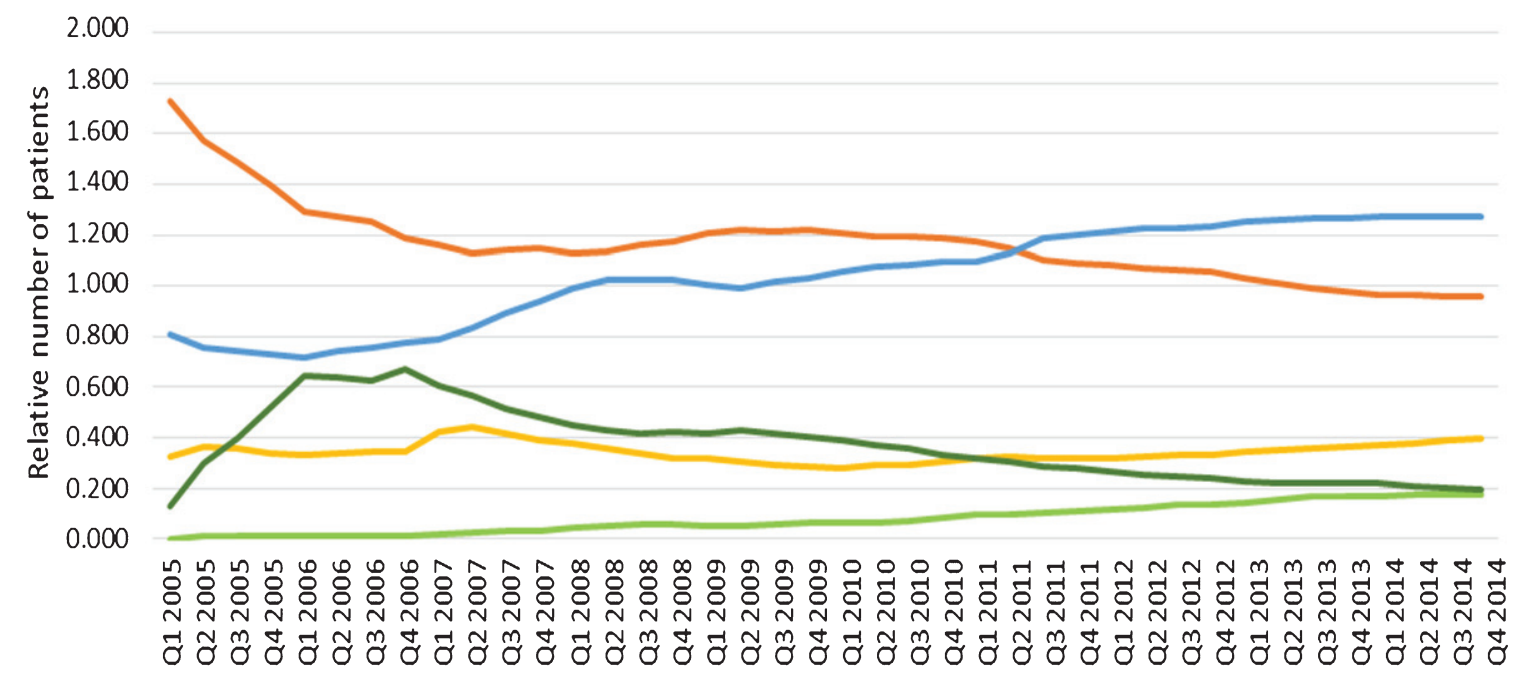

C

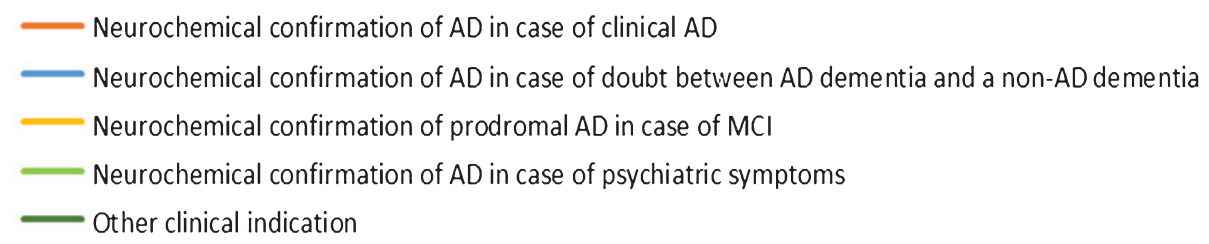

Fig. 3. A) Number of unique samples analyzed per year. B) Number of unique samples per year, grouped by location of referring centers. C) Representation of the number of patients for each indication relative to the total amount of patients per quartile.

Table 4

Diagnostic accuracies for the differentiation of $\mathrm{AD}$ and non-AD dementia. The optimal cutoff values were determined by calculation of the maximal sum of the sensitivity and the specificity. AUC, area under the curve; CI, confidence intervals; sens, sensitivity; spec, specificity

\begin{tabular}{lccccc}
\hline AD versus non-AD & AUC & $95 \%$ CI & Cutoff $(\mathrm{pg} / \mathrm{ml})$ & Sens $(\%)$ & Spec $(\%)$ \\
\hline T-tau & 0.670 & $0.474-0.660$ & 414 & 65.5 & 56.2 \\
$\mathrm{~A} \beta_{1-42}$ & 0.647 & $0.555-0.739$ & 615 & 90.0 & 38.7 \\
$\mathrm{P}-\operatorname{tau} 181 \mathrm{P}$ & 0.676 & $0.591-0.760$ & 54.5 & 65.7 & 63.9 \\
$\mathrm{~A} \beta_{1-42} / \mathrm{T}-\mathrm{tau}$ & 0.635 & $0.544-0.726$ & 1.55 & 80.8 & 45.9 \\
$\mathrm{~A} \beta_{1-42} / \mathrm{P}-\operatorname{tau}_{181 \mathrm{P}}$ & 0.734 & $0.655-0.813$ & 9.05 & 73.5 & 63.9 \\
\hline
\end{tabular}



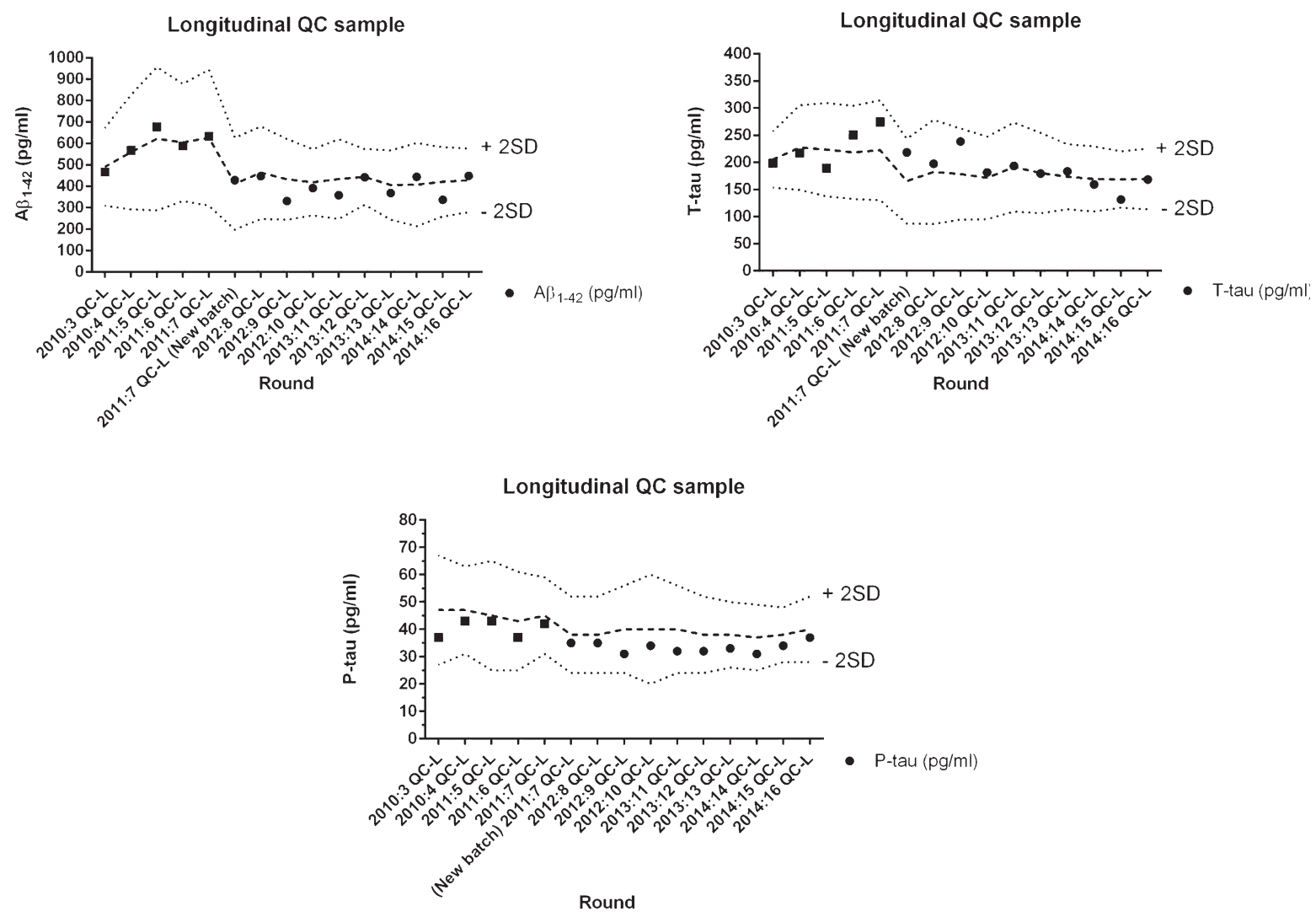

Fig. 4. CSF biomarker results of the first and second QC-L samples for $\mathrm{A} \beta_{1-42}$, T-tau, and P-tau $181 \mathrm{P}$. Our results are plotted (filled squares batch 1, filled circles batch 2) against the mean value (dashed line) with their 2 SD ranges (dotted lines) of all participating laboratories.

and specificity $63.9 \%$ ) than $\mathrm{A} \beta_{1-42}$ (sensitivity of $90.0 \%$ and specificity $38.7 \%$ ), T-tau (sensitivity of $65.5 \%$ and specificity $56.2 \%$ ), P-tau $181 \mathrm{P}$ (sensitivity of $65.7 \%$ and specificity of $63.9 \%$ ), or the $A \beta_{1-42} / \mathrm{T}$ tau ratio (sensitivity of $80.8 \%$ and specificity $45.9 \%$ ), while P-tau $181 \mathrm{P}$ was found to perform better than $\mathrm{A} \beta_{1-42}$ or T-tau to discriminate between $\mathrm{AD}$ and non-AD dementias (Table 4). This clearly signifies the importance of P-tau $181 \mathrm{P}$ in the biomarker panel for differential dementia diagnosis [14]. Concomitant AD pathology in DLB, which occurred in $72 \%$ of the autopsy-confirmed DLB patients, is reflected by low CSF $A \beta_{1-42}$ values in these patients [35]. However, the differential diagnostic value against pure $A D$ is limited due to the fact that only AD pathology will be detected because of a lack of established CSF DLB biomarkers. Very high T-tau concentrations in CSF $(>1200 \mathrm{pg} / \mathrm{ml})$ are indicative for CJD. In case of suspicion of CJD, analysis of CSF 14-3-3 protein can be useful.

The differential diagnostic value of the existing biomarker panel might be improved by the addition of $A \beta_{1-40}$, as this biomarker better reflects the total pool of $A \beta$. As the analysis of $A \beta_{1-42}$ may lead to false negative values in case of "high $A \beta$ producers", normalizing the CSF $A \beta_{1-42}$ concentration to that of the most abundant and stably produced $A \beta$ isoform (i.e. $\left.A \beta_{1-40}\right)$ may improve the diagnostic value for these samples [36-39]. Since formation of amyloidplaques starts up to twenty years before the onset of the clinical symptoms, the use of low CSF $A \beta_{1-42}$ and the $C S F A \beta_{1-42} / A \beta_{1-40}$ ratio opens new possibilities for the identification of 'asymptomatic at risk for AD' subjects for clinical trials [40]. Differential diagnosis of $\mathrm{AD}$ versus non-AD dementia may also benefit of adding other $A \beta$ isoforms [41] as well as other biomarkers, such as $\alpha$-synuclein $[42,43]$ and TDP-43 [44], as they are specific for non-AD dementias.

Even with an elevated confidence in the use of CSF biomarkers for the clinical work-up of dementia diagnosis, multicenter trials have shown that there is a substantial center-to-center variation [45]. The different pre-analytical sample procedures used by the different centers contribute to variability of CSF 
biomarker concentrations. This causes an important concern as direct comparisons of measurements between laboratories and across techniques are not reliable, hampering biomarker development and their utility for clinical routine diagnosis [46]. Temperature of freezing, delay until freezing and number of freezethaw cycles significantly influence CSF biomarker concentrations, stressing the need for standard operating procedures for pre-analytical sample handling [47]. The differences observed in the latter study were, however, relatively small. An exploratory study in MCI patients with clinical follow-up and autopsyconfirmed AD patients provided evidence that, for a specific context of use, the impact on clinical diagnostic accuracy of biomarker concentration shifts might be lower than originally expected [46]. However, standardization of (pre)analytical sample handling as well as the cutoff thresholds should be accomplished as they influence biomarker results [47, 48]. With this in mind, several programs for standardization and harmonization were set up, such as the QC program of the Alzheimer's Association, as well as the Alzheimer Biomarker Standardization Initiative (ABSI) and the JPND BIOMARKAPD consortium [49-52].

\section{CONCLUSION}

This paper provides insight in the use of CSF biomarkers for the clinical diagnostic work-up of $\mathrm{AD}$ and related disorders in Belgium during the past decade. Within this period, over 5,000 CSF samples have been analyzed. Several research papers found their origin in the AD CSF biomarker analyses, with a significant contribution of subjects who gave informed consent for brain autopsy. Studies on autopsy-confirmed $\mathrm{AD}$ patients that do not comply with the criteria for a neurochemical diagnosis of $A D$, which accounted for $30 \%$ of the definite diagnoses, are needed to improve our insights in the boundaries of the current AD CSF biomarkers. Improving the quality of CSF biomarker analyses for AD diagnosis can be accomplished by complying with recommendations of standardization programs.

\section{ACKNOWLEDGMENTS}

This work was funded in part by the University of Antwerp Research Fund; the Alzheimer Research Foundation (SAO-FRA, http://alzh.org); the Institute Born-Bunge (IBB, http://www.bornbunge.be); the Belgian Science Policy Office Interuniversity Attraction Poles (IAP) program (BELSPO, http://www.belspo.be); the Flemish Government initiated Methusalem excellence grant (EWI, http:// www.ewi-vlaanderen.be); the Flanders Impulse Program on Networks for Dementia Research (VIND); the Agency for Innovation by Science and Technology (IWT, http://www.iwt.be); and the Research Foundation Flanders (FWO, http://www.fwo.be).

Authors' disclosures available online (http://jalz.com/manuscript-disclosures/15-1097r2).

\section{REFERENCES}

[1] Hansson O, Zetterberg H, Buchhave P, Londos E, Blennow K, Minthon L (2006) Association between CSF biomarkers and incipient Alzheimer's disease in patients with mild cognitive impairment: A follow-up study. Lancet Neurol 5, 228-234.

[2] Engelborghs S, De Vreese K, Van de Casteele T, Vanderstichele H, Van Everbroeck B, Cras P, Martin JJ, Vanmechelen E, De Deyn PP (2008) Diagnostic performance of a CSF-biomarker panel in autopsy-confirmed dementia. Neurobiol Aging 29, 1143-1159.

[3] Mulder C, Verwey NA, van der Flier WM, Bouwman FH, Kok A, van Elk EJ, Scheltens P, Blankenstein MA (2010) Amyloid- $\beta_{(1-42)}$, total tau, and phosphorylated tau as cerebrospinal fluid biomarkers for the diagnosis of Alzheimer disease. Clin Chem 56, 248-253.

[4] Mattsson N, Zetterberg H, Hansson O, Andreasen N, Parnetti L, Jonsson M, Herukka SK, van der Flier WM, Blankenstein MA, Ewers M, Rich K, Kaiser E, Verbeek M, Tsolaki M, Mulugeta E, Rosén E, Aarsland D, Visser PJ, Schröder J, Marcusson J, de Leon M, Hampel H, Scheltens P, Pirttilä T, Wallin A, Jönhagen ME, Minthon L, Winblad B, Blennow K (2009) CSF biomarkers and incipient Alzheimer disease in patients with mild cognitive impairment. JAMA 302, 385 .

[5] Hulstaert F, Blennow K, Ivanoiu A, Schoonderwaldt HC, Riemenschneider M, Deyn PP, Bancher C, Cras P, Wiltfang J, Mehta PD, Igbal K, Pottel H, Vanmechelen E, Vanderstichele $H$ (1999) Improved discrimination of AD patients using $\beta$-amyloid(1-42) and tau levels in CSF. Neurology 52, 1555 .

[6] Visser PJ, Verhey F, Knol DL, Scheltens P, Wahlund L, Freund-Levi Y, Tsolaki M, Wallin AK, Hampel H, Bürger K, Pirttila T, Soininen H, Rikkert MO, Verbeek MM, Spiru L, Blennow K (2009) Prevalence and prognostic value of CSF markers of Alzheimer's disease pathology in patients with subjective cognitive impairment or mild cognitive impairment in the DESCRIPA study: A prospective cohort study. Lancet Neurol 8, 619-627.

[7] Blennow K, Hampel H, Weiner M, Zetterberg H (2010) Cerebrospinal fluid and plasma biomarkers in Alzheimer disease. Nat Rev Neurol 6, 131-144.

[8] Le Bastard N, Coart E, Vanderstichele H, Martin J, Engelborghs S (2013) Comparison of two analytical platforms for the clinical qualification of Alzheimer's disease biomarkers in pathologically-confirmed dementia. JAlzheimers Dis 33, 117-131.

[9] Albert MS, DeKosky ST, Dickson D, Dubois B, Feldman HH, Fox NC, Gamst A, Holtzman DM, Jagust WJ, Petersen RC, Snyder PJ, Carrillo Mc, Thies B, Phelps CH (2011) The diagnosis of mild cognitive impairment due to Alzheimer's 
disease: Recommendations from the National Institute on Aging-Alzheimer's Association workgroups on diagnostic guidelines for Alzheimer's disease. Alzheimers Dement 7, 270-279.

[10] Dubois B, Feldman HH, Jacova C, Hampel H, Molinuevo JL, Blennow K, DeKosky ST, Gauthier S, Selkoe D, Bateman R, Cappa S, Crutch S, Engelborghs S, Frisoni GB, Fox NC, Galasko D, Habert MO, Jicha GA, Nordberg A, Pasquier F, Rabinovici G, Robert P, Rowe C, Salloway S, Sarazin M, Epelbaum S, de Souza LC, Vellas B, Visser PJ, Schneider L, Stern Y, Scheltens P, Cummings JL (2014) Advancing research diagnostic criteria for Alzheimer's disease: The IWG-2 criteria. Lancet Neurol 13, 614629.

[11] McKhann GM, Knopman DS, Chertkow H, Hyman BT, Jack CR Jr, Kawas CH, Klunk WE, Koroshetz WJ, Manly JJ, Mayeux R, Mohs RC, Morris JC, Rossor MN, Scheltens P, Carrillo MC, Thies B, Weintraub S, Phelps $\mathrm{CH}$ (2011) The diagnosis of dementia due to Alzheimer's disease: Recommendations from the National Institute on Aging-Alzheimer's Association workgroups on diagnostic guidelines for Alzheimer's disease. Alzheimers Dement 7, 263-269.

[12] Bier J, Verschraegen J, Vandenberghe R, Guillaume B, Picard G, Otte G, Mormont E, Gilles C, Segers K, Sieben A, Thiery E, Ventura M, De Deyn P, Deryck O, Versijpt J, Salmon E, Engelborghs S, Ivanoiu A (2015) Clinical utility and applicability of biomarker-based diagnostic criteria for Alzheimer's disease: A BeDeCo survey. Acta Neurol Belg 115, 547-555.

[13] Le Bastard N, Martin J, Vanmechelen E, Vanderstichele H, De Deyn PP, Engelborghs S (2010) Added diagnostic value of CSF biomarkers in differential dementia diagnosis. Neurobiol Aging 31, 1867-1876.

[14] Struyfs H, Niemantsverdriet E, Goossens J, Fransen E, Martin J, De Deyn PP, Engelborghs S (2015) Cerebrospinal fluid P-Tau181P: Biomarker for improved differential dementia diagnosis. Front Neurol 6, 138.

[15] Engelborghs S (2013) Clinical indications for analysis of Alzheimer's disease CSF biomarkers. Rev Neurol (Paris) 169, 709-714.

[16] Niemantsverdriet E, Feyen BFE, Le Bastard N, Martin J, Goeman J, De Deyn PP, Engelborghs S (2015) Overdiagnosing vascular dementia using structural brain imaging for dementia work-up. J Alzheimers Dis 45, 1039-1043.

[17] Engelborghs S, Le Bastard N (2012) The role of CSF biomarkers in the diagnostic work-up of mixed vasculardegenerative dementia. J Neurol Sci 322, 197-199.

[18] Folstein MF, Folstein SE, McHugh PR (1975) Mini-mental state. A practical method for grading the cognitive state of patients for the clinician. J Psychiatr Res 12, 189-198.

[19] Cuadrado-Corrales N, Jiménez-Huete A, Albo C, Hortigüela R, Vega L, Cerrato L, Sierra-Moros M, Rábano A, de Pedro-Cuesta J, Calero M (2006) Impact of the clinical context on the 14-3-3 test for diagnosis of sporadic CJD. BMC Neurol 6, 25.

[20] Zerr I, Bodemer M, Gefeller O, Otto M, Poser S, Wiltfang J, Windl O, Kretzschmar HA, Weber T (1998) Detection of 143-3 protein in the cerebrospinal fluid supports the diagnosis of Creutzfeldt-Jakob disease. Ann Neurol 43, 32.

[21] Van Everbroeck B (2003) A prospective study of CSF markers in 250 patients with possible Creutzfeldt-Jakob disease. J Neurol Neurosurg Psychiatry 74, 1210.

[22] Van Everbroeck B, Boons J, Cras P (2005) 14-3-3 $\gamma$-isoform detection distinguishes sporadic Creutzfeldt-
Jacob disease from other dementias. J Neurol Neurosurg Psychiatry 76, 100-102.

[23] Van der Mussele S, Fransen E, Struyfs H, Luyckx J, Mariën P, Saerens J, Somers N, Goeman J, De Deyn PP, Engelborghs S (2014) Depression in mild cognitive impairment is associated with progression to Alzheimer's disease: A longitudinal study. J Alzheimers Dis 42, 1239-1250.

[24] Mattsson N, Andreasson U, Persson S, Carrillo MC, Collins S, Chalbot S, Cutler N, Dufour-Rainfray D, Fagan AM, Heegaard NH, Robin Hsiung GY, Hyman B, Iqbal K, Kaeser SA, Lachno DR, Lleó A, Lewczuk P, Molinuevo JL, Parchi P, Regeniter A, Rissman RA, Rosenmann H, Sancesario G, Schröder J, Shaw LM, Teunissen CE, Trojanowski JQ, Vanderstichele H, Vandijck M, Verbeek MM, Zetterberg H, Blennow K, Alzheimer's Association QC Program Work Group (2013) CSF biomarker variability in the Alzheimer's Association quality control program. Alzheimers Dement $\mathbf{9}$, 251-261.

[25] Montine TJ, Phelps CH, Beach TG, Bigio EH, Cairns NJ, Dickson DW, Duyckaerts C, Frosch MP, Masliah E, Mirra SS, Nelson PT, Schneider JA, Thal DR, Trojanowski JQ, Vinters HV, Hyman BT; National Institute on Aging; Alzheimer's Association (2011) National Institute on Aging-Alzheimer's Association guidelines for the neuropathologic assessment of Alzheimer's disease: A practical approach. Acta Neuropathol 123, 1-11.

[26] Cairns NJ, Bigio EH, Mackenzie IRA, Neumann M, Hatanpaa KJ, White CL3rd, Schneider JA, Grinberg LT, Halliday G, Duyckaerts C, Lowe JS, Holm IE, Tolnay M, Okamoto K, Yokoo H, Murayama S, Woulfe J, Munoz DG, Dickson DW, Ince PG, Trojanowski JQ, Mann DM; Consortium for Frontotemporal Lobar Degeneration (2007) Neuropathologic diagnostic and nosologic criteria for frontotemporal lobar degeneration: Consensus of the Consortium for Frontotemporal Lobar Degeneration. Acta Neuropathol 114, 22.

[27] Mackenzie IRA, Neumann M, Baborie A, Sampathu DM, Du Plessis D, Jaros E, Jaros E, Perry RH, Trojanowski JQ, Mann DM, Lee VM (2011) A harmonized classification system for FTLD-TDP pathology. Acta Neuropathol 122, 111-113.

[28] Mackenzie IRA, Neumann M, Bigio EH, Cairns NJ, Alafuzoff I, Kril J, Kovacs GG, Ghetti B, Halliday G, Holm IE, Ince PG, Kamphorst W, Revesz T, Rozemuller AJ, Kumar-Singh S, Akiyama H, Baborie A, Spina S, Dickson DW, Trojanowski JQ, Mann DM (2009) Nomenclature and nosology for neuropathologic subtypes of frontotemporal lobar degeneration: An update. Acta Neuropathol 119, 1-4.

[29] Markesbery WR (1998) Neuropathology of Dementing Disorders, Oxford Univ Press, London.

[30] Lléo A, Cavedo E, Parnetti L, Vanderstichele H, Herukka SK, Andreasen N, Ghidoni R, Lewczuk P, Jeromin A, Winblad B, Tsolaki M, Mroczko B, Visser PJ, Santana I, Svenningsson P, Blennow K, Aarsland D, Molinuevo JL, Zetterberg HH, Mollenhauer B (2014) Cerebrospinal fluid biomarkers in trials for Alzheimer and Parkinson diseases. Nat Rev Neurol 11, 41-55.

[31] Tang W, Huang Q, Wang Y, Wang Z, Yao Y (2014) Assessment of CSF A $\beta 42$ as an aid to discriminating Alzheimer's disease from other dementias and mild cognitive impairment: A meta-analysis of 50 studies. J Neurol Sci 345, 26-36.

[32] Meiner Z, Kahana E, Baitcher F, Korczyn AD, Chapman J, Cohen OS, Milo R, Aharon-Perez J, Abramsky O, 
Gabizon R, Rosenmann H (2010) Tau and 14-3-3 of genetic and sporadic Creutzfeldt-Jakob disease patients in Israel. $J$ Neurol 258, 255.

[33] Mukaetova-Ladinska EB, Monteith R, Perry EK (2010) Cerebrospinal fluid biomarkers for dementia with Lewy bodies. Int J Alzheimers Dis 2010, 536538.

[34] Engelborghs S, Sleegers K, Cras P, Brouwers N, Serneels S, De Leenheir E, Martin JJ, Vanmechelen E, Van Broeckhoven C, De Deyn PP (2007) No association of CSF biomarkers with APOE $\varepsilon 4$, plaque and tangle burden in definite Alzheimer's disease. Brain 130, 2320.

[35] Slaets S, Le Bastard N, Theuns J, Sleegers K, Verstraeten A, De Leenheir E, Luyckx J, Martin JJ, Van Broeckhoven C, Engelborghs S (2013) Amyloid pathology influences $A \beta 1$ 42 cerebrospinal fluid levels in dementia with Lewy bodies. J Alzheimers Dis 35, 137-146.

[36] Slaets S, Le Bastard N, Martin J, Sleegers K, Van Broeckhoven C, De Deyn PP, Engelborghs S (2013) Cerebrospinal fluid $A \beta 1-40$ improves differential dementia diagnosis in patients with intermediate P-tau181P levels. J Alzheimers Dis 36, 759-767.

[37] Spies PE, Slats D, Sjogren JMC, Kremer BPH, Verhey FRJ, Rikkert MG, Verbeek MM (2010) The cerebrospinal fluid amyloid $\beta 42 / 40$ ratio in the differentiation of Alzheimer's disease from non-Alzheimer's dementia. Curr Alzheimer Res 7, 470.

[38] Sauvée M, DidierLaurent G, Latarche C, Escanyé M, Olivier J, Malaplate-Armand C (2014) Additional use of Abeta42/Abeta40 ratio with cerebrospinal fluid biomarkers P-Tau and Abeta42 increases the level of evidence of Alzheimer's disease pathophysiological proces in routine practice. J Alzheimers Dis 41, 377-386.

[39] Lewczuk P, Lelental N, Spitzer P, Maler JM, Kornhuber J (2015) Amyloid- $\beta$ 42/40 cerebrospinal fluid concentration ratio in the diagnosis of Alzheimer's disease: Validation of two novel assays. J Alzheimers Dis 43, 183-191.

[40] Jansen WJ, Ossenkoppele R, Knol DL, Tijms BM, Scheltens P, Verhey FRJ, Visser PJ, Amyloid Biomarker Study Group, Aalten P, Aarsland D, Alcolea D, Alexander M, Almdahl IS, Arnold SE, Baldeiras I, Barthel H, van Berckel BN, Bibeau K, Blennow K, Brooks DJ, van Buchem MA, Camus V, Cavedo E, Chen K, Chetelat G, Cohen AD, Drzezga A, Engelborghs S, Fagan AM, Fladby T, Fleisher AS, van der Flier WM, Ford L, Förster S, Fortea J, Foskett N, Frederiksen KS, Freund-Levi Y, Frisoni GB, Froelich L, Gabryelewicz T, Gill KD, Gkatzima O, Gómez-Tortosa E, Gordon MF, Grimmer T, Hampel H, Hausner L, Hellwig S, Herukka SK, Hildebrandt H, Ishihara L, Ivanoiu A, Jagust WJ, Johannsen P, Kandimalla R, Kapaki E, KlimkowiczMrowiec A, Klunk WE, Köhler S, Koglin N, Kornhuber J, Kramberger MG, Van Laere K, Landau SM, Lee DY, de Leon M, Lisetti V, Lleó A, Madsen K, Maier W, Marcusson J, Mattsson N, de Mendonça A, Meulenbroek O, Meyer PT, Mintun MA, Mok V, Molinuevo JL, Møllergård HM, Morris JC, Mroczko B, Van der Mussele S, Na DL, Newberg A, Nordberg A, Nordlund A, Novak GP, Paraskevas GP, Parnetti L, Perera G, Peters O, Popp J, Prabhakar S, Rabinovici GD, Ramakers IH, Rami L, Resende de Oliveira C, Rinne JO, Rodrigue KM, Rodríguez-Rodríguez E, Roe CM, Rot U, Rowe CC, Rüther E, Sabri O, Sanchez-Juan P, Santana I, Sarazin M, Schröder J, Schütte C, Seo SW, Soetewey F, Soininen H, Spiru L, Struyfs H, Teunissen CE, Tsolaki M, Vandenberghe R, Verbeek MM, Villemagne VL, Vos SJ, van Waalwijk van Doorn LJ, Waldemar G, Wallin A, Wallin $\AA$ K, Wiltfang J, Wolk DA, Zboch M, Zetterberg H
(2015) Prevalence of cerebral amyloid pathology in persons without dementia. JAMA 313, 1924-1915.

[41] Struyfs H, Van Broeck B, Timmers M, Fransen E, Sleegers K, Van Broeckhoven C, De Deyn PP, Streffer JR, Mercken M, Engelborghs S (2015) Diagnostic accuracy of cerebrospinal fluid amyloid- $\beta$ isoforms for early and differential dementia diagnosis. J Alzheimers Dis 45, 813-822.

[42] Slaets S, Vanmechelen E, Le Bastard N, Decraemer H, Vandijck M, Martin J, De Deyn PP, Engelborghs S (2014) Increased CSF $\alpha$-synuclein levels in Alzheimer's disease: Correlation with tau levels. Alzheimers Dement 10(S), S290S298.

[43] Simonsen AH, Kuiperij B, Ali El-Agnaf OM, Engelborghs S, Herukka SK, Parnetti L, Rektorova I, Vanmechelen E, Kapaki E, Verbeek M, Mollenhauer B (2016) The utility of $\alpha$-synuclein as biofluid marker in neurodegenerative diseases: A systematic review of the literature. Biomark Med 10, 19-34.

[44] Goossens J, Vanmechelen E, Trojanowski JQ, Lee VM, Van Broeckhoven C, van der Zee J, Engelborghs S (2015) TDP-43 as a possible biomarker for frontotemporal lobar degeneration: A systematic review of existing antibodies. Acta Neuropathol Commun 3, 15.

[45] Mattsson N, Zetterberg H, Blennow K (2010) Lessons from multicenter studies on CSF biomarkers for Alzheimer's disease. Int J Alzheimers Dis [2010], pii: 610613.

[46] Niemantsverdriet E, Goossens J, Struyfs H, Martin J, Goeman J, De Deyn PP, Vanderstichele H, Engelborghs S (2016) Diagnostic impact of cerebrospinal fluid biomarker variability in Alzheimer's disease. J Alzheimers Dis 51, 97-106.

[47] Le Bastard N, De Deyn PP, Engelborghs S (2015) Importance and impact of preanalytical variables on Alzheimer disease biomarker concentrations in cerebrospinal fluid. Clin Chem 61, 734-743.

[48] Bjerke M, Portelius E, Minthon L, Wallin A, Anckarsäter $\mathrm{H}$, Anckarsäter R, Andreasen N, Zetterberg H, Andreasson U, Blennow K (2010) Confounding factors influencing amyloid Beta concentration in cerebrospinal fluid. Int $J$ Alzheimers Dis 2010, pii: 986310.

[49] Molinuevo JL, Blennow K, Dubois B, Engelborghs S, Lewczuk P, Perret-Liaudet A, Teunissen CE, Parnetti L (2014) The clinical use of cerebrospinal fluid biomarker testing for Alzheimer's disease diagnosis: A consensus paper from the Alzheimer's Biomarkers Standardization Initiative. Alzheimers Dement 10, 1-10.

[50] Mattsson N, Andreasson U, Persson S, Arai H, Batish SD, Bernardini S, Bocchio-Chiavetto L, Blankenstein MA, Carrillo MC, Chalbot S, Coart E, Chiasserini D, Cutler N, Dahlfors G, Duller S, Fagan AM, Forlenza O, Frisoni GB, Galasko D,Galimberti D, Hampel H, Handberg A, Heneka MT, Herskovits AZ, Herukka SK, Holtzman DM, Humpel C, Hyman BT, Iqbal K, Jucker M, Kaeser SA, Kaiser E, Kapaki E, Kidd D, Klivenyi P, Knudsen CS, Kummer MP, Lui J, Lladó A, Lewczuk P, Li QX,Martins R, Masters C, McAuliffe J, Mercken M, Moghekar A, Molinuevo JL, Montine TJ, Nowatzke W, O'Brien R, Otto M,Paraskevas GP, Parnetti L, Petersen RC, Prvulovic D, de Reus HP, Rissman RA, Scarpini E, Stefani A, Soininen H,Schröder J, Shaw LM, Skinningsrud A, Skrogstad B, Spreer A, Talib L, Teunissen C, Trojanowski JQ, Tumani H, Umek RM,Van Broeck B, Vanderstichele H, Vecsei L, Verbeek MM, Windisch M, Zhang J, Zetterberg H, Blennow K (2011) The Alzheimer's Association external quality control program for cerebrospinal fluid biomarkers. Alzheimers Dement 7, 386-395.e6. 
[51] Vanderstichele H, Bibl M, Engelborghs S, Le Bastard N, Lewczuk P, Molinuevo JL, Parnetti L, Perret-Liaudet A, Shaw LM, Teunissen C, Wouters D, Blennow K (2012) Standardization of preanalytical aspects of cerebrospinal fluid biomarker testing for Alzheimer's disease diagnosis: A consensus paper from the Alzheimer's Biomarkers Standardization Initiative. Alzheimers Dement 8, 65-73.

[52] Bjerke M, Andreasson U, Kuhlmann J, Portelius E, Pannee J, Lewczuk P, Umek RM, Vanmechelen E, Vanderstichele H,
Stoops E, Lewis J, Vandijck M, Kostanjevecki V, Jeromin A, Salamone SJ, Schmidt O, Matzen A, Madin K, Eichenlaub U, Bittner T, Shaw LM, Zegers I, Zetterberg H, Blennow K (2016) Assessing the commutability of reference material formats for the harmonization of amyloid beta measurements. Clin Chem Lab Med 54, 1177-1191. 